\title{
Molecular Epidemiology of Bovine Papillomatosis and Identification of Three Genotypes in Central Iraq
}

\author{
Mohammed A. Hamad ${ }^{a} \quad$ Ahmed Majeed Al-Shammari ${ }^{b}$ Shoni M. Odisho ${ }^{c}$ \\ Nahi Y. Yaseen ${ }^{b}$ \\ a University of Fallujah College of Veterinary Medicine, Al-Anbar, Iraq; ${ }^{b}$ Experimental Therapy Department, Iraqi \\ Center for Cancer and Medical Genetic Research, Mustansiriyah University, Baghdad, Iraq; 'Baghdad University \\ College of Veterinary Medicine, Baghdad, Iraq
}

\section{Keywords}

Fibropapilloma · Bovine papillomatosis · Molecular epidemiology

\begin{abstract}
Objective: This study aims to provide a molecular and epidemiological characterization of bovine papillomavirus (BPV) infections in Iraq. Methods: The present study focuses on identifying BPV based on clinical and epidemiological manifestations, histopathological examinations, and polymerase chain reactions (PCR). Samples were collected from 163 animals suffering from cutaneous bovine papillomatosis, including 129 females (79.14\%) with an age range of 1640 months and 34 males (20.85\%) with an age range of $17-$ 29 months. Results: The incidence rate was significantly higher in females than in males. The most commonly affected sites were the teats and neck, though warts were found in other areas of the body. Histological sections were diagnosed as fibropapilloma. PCR results showed that $80.13 \%$ of the extracted papilloma DNA samples corresponded to the BPV-1 genotype. Furthermore, $7.94 \%$ of the samples showed a mixed infection of BPV-1 and BPV-13. While, $40.63 \%$ of the extracted DNA blood samples showed 2 DNA fragments corresponding to both genotypes BPV-1 and BPV-2. Conclu-
\end{abstract}

sions: This study confirmed the presence of BPV-1, BPV-2, and BPV-13, which belong to the Deltapapillomavirus genera, for the first time in the DNA of Iraqi cattle. Understanding BPV diversity and epidemiology is of critical importance for starting prevention strategies.

(c) 2018 S. Karger AG, Basel

\section{Introduction}

Bovine papillomaviruses (BPV) are causative agents of benign and malignant tumors in cattle, such as cutaneous papillomas, fibropapillomas, and urinary bladder and esophageal cancers $[1,2]$. There are 14 types of BPV, which have been classified into 3 separate genera: Delta, Epsilon, and Xi. Each can cause type-specific lesions [3, 4]. BPV-1, BPV-2, and BPV-13, for example, are classified in the Deltapapillomavirus genus and induce fibropapilloma [5]. They are also capable of infecting diverse host species, causing equine sarcoid [6-8]. Lesions of the teats and udders in cattle are commonly related to BPV-1

This work was done at the Experimental Therapy Department Laboratories, Iraqi Center for Cancer and Medical Genetic Research, Mustansiriyah University, Baghdad, Iraq.

\section{KARGER}

(c) 2018 S. Karger AG, Basel

E-Mail karger@karger.com

www.karger.com/int
Ahmed Majeed Al-Shammari

Experimental Therapy Department

Iraqi Center for Cancer and Medical Genetic Research, Mustansiriyah University

Al-Qadisiyah Q., Sec. 603, Street 23, Baghdad 1001 (Iraq)

E-Mail ahmed.alshammari@iccmgr.org 
Table 1. Thirteen genotypes of BPV sequences with their gene bank accession numbers used for primer designing

\begin{tabular}{rll}
\hline No. & Genotype & NCBI accession No. \\
\hline 1 & BPV-1 & $\begin{array}{l}\text { BPV-1 X02346, BPV-1 NC_001522, Japan Hokkaido AB626705, BPV-1 isolate EqSarc1 } \\
\text { and BPV-1 JX678969 }\end{array}$ \\
2 & BPV-2 & BPV-2 isolate SW KC878306 and BPV-2 M20219 \\
3 & BPV-3 & BPV-3, AF486184 and BPV-3, AJ620207 \\
4 & BPV-4 & BPV-4 genome X05817 \\
5 & BPV-5 & BPV-5, NC_004195, BPV-5, AF457465, BPV-5, AJ620206 and BPV-5, BAA5-Japan, \\
6 & BPV-6 & BPV-6, AB845589 and BPV-6, AJ620208 \\
7 & BPV-7 & BPV-7, NC_007612 and BPV-7, DQ217793 \\
8 & BPV-8 & BPV-8-EB, DQ098917 and BPV-8, DQ098913 \\
9 & BPV-9 & BPV-9 DNA, AB331650 \\
10 & BPV-10 & BPV-10, AB331651 and BPV-10 isolate MYP55, KF017607 \\
11 & BPV-11 & BPV-11 DNA, AB543507 \\
12 & BPV-12 & BPV-12 isolate PR000002, JF834524 and BPV-12 isolate PR000001, JF834523 \\
13 & BPV-13 & BPV-13 strain Hainan, KM258443 and BPV-13 JQ798171 \\
\hline
\end{tabular}

BPV, bovine papilloma virus.

$[9,10]$. Fibropapilloma in the penis is also associated with BPV-1 and leads to necrosis and loss of reproductive function [11]. In cutaneous fibropapilloma, BPV-2 is a causative agent of malignant bladder tumors [9]. Most of these types of viruses have also been detected in the peripheral blood and reproductive tissue samples of cattle, resulting in vertical transmission [12-14]. BPV Xipapillomavirus types (i.e., 3, 4, 6, 9, 10, 11, and 12) are considered selective epitheliotropic viruses, inducing the formation of true papillomas $[9,15,16]$. In contrast, the BPV Epsilonpapillomavirus types (i.e., 5 and 8) can induce fibropapillomas and true papillomas [17]. BPV-7 is grouped separately [18].

$\mathrm{BPV}$-induced benign lesions regress spontaneously; however, they may develop into cancer, especially in the presence of cofactors such as environmental carcinogens [19]. BPV diagnosis usually includes a clinical examination, histopathology, and immunohistochemistry [20, 21]. Polymerase chain reaction (PCR) has been used as a sensitive method for the identification and genotyping of BPV [22-24]. Specific primers have also been successfully employed mainly for BPV identification in blood [25, 26]. BPV contains a double-stranded, circular, 8-kb DNA genome divided into the following 3 regions: (1) an early region, (2) a long control region, and (3) a late region, which encodes several important proteins [27].

Bovine papillomatosis has been reported in some Middle Eastern countries, such as Turkey and Saudi Arabia, where BPV-1 has been detected [28, 29]. It has also been reported in Iran [30]. Hamad et al. [31] were the first to report the presence of BPV-1 in Iraq as the main causative agent of bovine papillomatosis in Iraqi cattle. Moreover, Hamad et al. [32] cultured skin warts collected from cattle to establish a cell culture for further studies. A successful long-term culture was achieved, and the cultured cells were used to prepare vaccines for wart recurrence prevention in BPV-infected cattle [33]. Cattle are an important source of dairy and beef products in Iraq [34], and bovine papillomatosis is responsible for significant economic losses for Iraqi cattle breeders [31]. The importance and breadth of the disease in Iraq makes it necessary to study the epidemiology and main genotypes causing this disease in Iraq, which can help control the disease.

\section{Materials and Methods}

\section{Animal and Sample Collection}

In this study, registered veterinarians from the cities of Anbar, Baghdad, and Diwaniyah collected cutaneous papilloma samples from 163 cattle (Holstein and crossbred Holstein Friesian breeds) in different parts of central Iraq. The study samples included cows suffering from bovine papillomatosis that were brought to private clinics by their owners between December 2013 and May 2015. We collected cutaneous papilloma tissue specimens from 131 animals and both cutaneous papilloma tissues and blood from an additional 20 animals. In addition, 12 blood samples without tissue were collected in EDTA tubes from animals infected with cutaneous papilloma. The collected tissue samples had varying diameters $(1-10 \mathrm{~cm})$ and came from different parts of the body (e.g., udder, teat, abdomen, and back). Each sample was immediately divided 
Table 2. Primers designed for BPV genotyping

\begin{tabular}{|c|c|c|c|c|c|}
\hline \multirow[t]{2}{*}{ Genotype } & \multirow{2}{*}{$\begin{array}{l}\text { Primer } \\
\left(5^{\prime}-3^{\prime}\right)\end{array}$} & \multicolumn{2}{|c|}{ Location } & \multirow{2}{*}{$\begin{array}{l}\text { Accession } \\
\text { No. }\end{array}$} & \multirow{2}{*}{$\begin{array}{l}\text { Product } \\
\text { length, bp }\end{array}$} \\
\hline & & start & end & & \\
\hline BPV-1 & $\begin{array}{l}\text { Forward } \\
\text { AGGAGGGTCATGCTTTGCTC } \\
\text { Reverse } \\
\text { GCTGTTCGGAGTGGTGTGTA }\end{array}$ & $\begin{array}{l}3,575 \\
4,422\end{array}$ & $\begin{array}{l}3,594 \\
4,403\end{array}$ & AB626705 & 847 \\
\hline BPV-2 & $\begin{array}{l}\text { Forward } \\
\text { GTCTTGGAGCTGCAACCTCT } \\
\text { Reverse } \\
\text { CAAGGCGTGCTCTTCACCTA }\end{array}$ & $\begin{array}{l}4,698 \\
5,300\end{array}$ & $\begin{array}{l}4,717 \\
5,281\end{array}$ & M20219 & 603 \\
\hline BPV-3 & $\begin{array}{l}\text { Forward } \\
\text { CACTGGGATGTTGCACAA GC } \\
\text { Reverse } \\
\text { ACTGGGGGATCCGAAGTACA }\end{array}$ & $\begin{array}{l}6,134 \\
6,526\end{array}$ & $\begin{array}{l}6,153 \\
6,507\end{array}$ & AJ620207 & 393 \\
\hline BPV -4 & $\begin{array}{l}\text { Forward } \\
\text { CGATCACGATCGCCTACGAA } \\
\text { Reverse } \\
\text { TGCCGCGTCTATAAGCTG AG }\end{array}$ & $\begin{array}{l}3,523 \\
3,719\end{array}$ & $\begin{array}{l}3,542 \\
3,738\end{array}$ & X05817 & 216 \\
\hline BPV-5 & $\begin{array}{l}\text { Forward } \\
\text { GCCAGGGCTTGGAACCTATT } \\
\text { Reverse } \\
\text { CTGCTGTGTGTTGCAGTGAC }\end{array}$ & $\begin{array}{l}4,185 \\
5,176\end{array}$ & $\begin{array}{l}4,204 \\
5,157\end{array}$ & NC_004195 & 992 \\
\hline BPV-5 & $\begin{array}{l}\text { Forward } \\
\text { ACGTGCAATTAGCCAGTCCA } \\
\text { Reverse } \\
\text { AAATCCACATCCACGGGACC }\end{array}$ & $\begin{array}{l}4,892 \\
5,435\end{array}$ & $\begin{array}{l}4,911 \\
5,416\end{array}$ & NC_004195 & 544 \\
\hline BPV-6 & $\begin{array}{l}\text { Forward } \\
\text { ACGTTGCCAGACCTACAGTG } \\
\text { Reverse } \\
\text { CTGGCAGTTGTGTGCTTGAC }\end{array}$ & $\begin{array}{l}4,288 \\
4,620\end{array}$ & $\begin{array}{l}4,307 \\
4,601\end{array}$ & AB845589 & 333 \\
\hline BPV-6 & $\begin{array}{l}\text { Forward } \\
\text { GTTGCCAGACCTACAGTGCT } \\
\text { Reverse } \\
\text { TGAAATTCTGCAAGCGGTGC }\end{array}$ & $\begin{array}{l}4,290 \\
4,974\end{array}$ & $\begin{array}{l}4,309 \\
4,993\end{array}$ & AB845589 & 704 \\
\hline BPV-7 & $\begin{array}{l}\text { Forward } \\
\text { ATTAAGGGACCGCTTTGGGG } \\
\text { Reverse } \\
\text { TCGGACGTTGACACACTCAG }\end{array}$ & $\begin{array}{r}60 \\
751\end{array}$ & 79 & NC_007612 & 692 \\
\hline BPV -8 & $\begin{array}{l}\text { Forward } \\
\text { TAGCGCTGATGCCAAAGGAA } \\
\text { Reverse } \\
\text { ACGAGAAGGAGAGTCAGGCT }\end{array}$ & $\begin{array}{l}3,021 \\
3,270\end{array}$ & $\begin{array}{l}3,040 \\
3,251\end{array}$ & DQ098913 & 250 \\
\hline BPV-8 & $\begin{array}{l}\text { Forward } \\
\text { AGCTTTGCAAACAGTGCGAG } \\
\text { Reverse } \\
\text { CATTGGCTGTTGCAGTTGCT }\end{array}$ & $\begin{array}{l}2,172 \\
2,776\end{array}$ & $\begin{array}{l}2,191 \\
2,757\end{array}$ & DQ098913 & 605 \\
\hline BPV-9 & $\begin{array}{l}\text { Forward } \\
\text { TGCCACACATTCCCATCCTC } \\
\text { Reverse } \\
\text { ACATTCGCCCCTTTACCAGG }\end{array}$ & $\begin{array}{l}3,860 \\
4,326\end{array}$ & $\begin{array}{l}3,879 \\
4,307\end{array}$ & AB331650 & 467 \\
\hline
\end{tabular}


Table 2 (continued)

\begin{tabular}{|c|c|c|c|c|c|}
\hline \multirow[t]{2}{*}{ Genotype } & \multirow{2}{*}{$\begin{array}{l}\text { Primer } \\
\left(5^{\prime}-3^{\prime}\right)\end{array}$} & \multicolumn{2}{|c|}{ Location } & \multirow{2}{*}{$\begin{array}{l}\text { Accession } \\
\text { No. }\end{array}$} & \multirow{2}{*}{$\begin{array}{l}\text { Product } \\
\text { length, bp }\end{array}$} \\
\hline & & start & end & & \\
\hline BPV-9 & $\begin{array}{l}\text { Forward } \\
\text { GACAGCCTAGAAGCCCGTTT } \\
\text { Reverse } \\
\text { CCACTTGTTCAGCAGTTGGC }\end{array}$ & $\begin{array}{l}2,838 \\
3,732\end{array}$ & $\begin{array}{l}2,857 \\
3,713\end{array}$ & AB331650 & 895 \\
\hline BPV-10 & $\begin{array}{l}\text { Forward } \\
\text { GGACAAATGGCACAGGGGTA } \\
\text { Reverse } \\
\text { CTGTTGTACGACGCTGGAGT }\end{array}$ & $\begin{array}{l}3,040 \\
3,442\end{array}$ & $\begin{array}{l}3,059 \\
3,423\end{array}$ & AB331651 & 403 \\
\hline BPV-10 & $\begin{array}{l}\text { Forward } \\
\text { AGACGACCAAGCGCAATGTA } \\
\text { Reverse } \\
\text { ACGAGGGCTCCTGTTACTCT }\end{array}$ & $\begin{array}{l}744 \\
962\end{array}$ & $\begin{array}{l}763 \\
981\end{array}$ & AB331651 & 238 \\
\hline BPV-11 & $\begin{array}{l}\text { Forward } \\
\text { GCCTGCAACTAGGGTCTCTG } \\
\text { Reverse } \\
\text { TAGATCGCGATGACGACTGC }\end{array}$ & $\begin{array}{l}2,940 \\
3,499\end{array}$ & $\begin{array}{l}2,959 \\
3,480\end{array}$ & AB543507 & 560 \\
\hline BPV-12 & $\begin{array}{l}\text { Forward } \\
\text { ACCAGGACGATGAGCCTACT } \\
\text { Reverse } \\
\text { GTCCTGTCGATGGAAGCCAA }\end{array}$ & $\begin{array}{l}1,315 \\
1,598\end{array}$ & $\begin{array}{l}1,334 \\
1,579\end{array}$ & JF834524 & 284 \\
\hline BPV-13 & $\begin{array}{l}\text { Forward } \\
\text { AACCACACCCGGTACACATC } \\
\text { Reverse } \\
\text { AGGAAGCAGGAATCAGTGCC }\end{array}$ & $\begin{array}{l}7,213 \\
7,293\end{array}$ & $\begin{array}{l}7,232 \\
7,312\end{array}$ & KM258443 & 100 \\
\hline BPV-13 & $\begin{array}{l}\text { Forward } \\
\text { CAGGGCTACGGTTTTGGGAT } \\
\text { Reverse } \\
\text { GTTTCTTGCCAGCAAAGCGA }\end{array}$ & $\begin{array}{l}6,936 \\
7,348\end{array}$ & $\begin{array}{l}6,955 \\
7,329\end{array}$ & KM258443 & 413 \\
\hline
\end{tabular}

$\mathrm{BPV}$, bovine papilloma virus.

into 2 parts, which were either frozen in a deep freezer for subsequent molecular biology analysis or fixed in $10 \%$ neutral buffered formalin for histological analysis. In addition, 5 esophageal tumor samples were collected from 5 cattle from a slaughterhouse.

\section{Histopathological Analysis}

Tissue samples were fixed in $10 \%$ buffered formalin and then dehydrated in ethanol and embedded in paraffin. The samples were cut into 5 - $\mu$ m-thick sections, deparaffinized with xylene, and rehydrated with distilled water. They were then placed on slides and stained using hematoxylin and eosin. The slides were evaluated under a microscope at different magnifications.

\section{Polymerase Chain Reaction}

A Magnesia ${ }^{\circledR}$ Genomic DNA Tissue Kit (Anatolia Geneworks, Istanbul, Turkey) was used to extract viral DNA from frozen tissue samples on a Magnesia ${ }^{\circledR} 16$ magnetic bead extraction system (Anatolia Geneworks) according to the manufacturer's instruc- tions. To study the main genotypes that induce the disease, a whole set of primers was designed for the 13 available genotypes. We aligned all BPV genomes for each genotype available at the National Center for Biotechnology Information (NCBI) GenBank website (Table 1) to find the most conserved regions of the BPV genome to create a primer specifically designed for BPV (Table 2). The primers were designed manually using A Plasmid Editor (ApE) software $(\mathrm{v} 2.0 .49,2015)$ to align the complete genome sequences and to choose the conserved regions between sequences. All primer sets were validated. Amplification was performed using a SureCycler 8800 Thermal Cycler (Agilent Technologies, Santa Clara, CA, USA) in a final volume of $25 \mu \mathrm{L}$, containing 100-300 ng of DNA, $2 \mathrm{mM}$ of $\mathrm{MgCl}_{2}, 1.25 \mu \mathrm{L}$ of primers $(0.5 \mu \mathrm{M})$, and $12.5 \mu \mathrm{L}$ of $1 \times$ KAPA2G Robust HotStart ReadyMix (Kapa Biosystems, Cape Town, South Africa). The amplification protocol included an initial denaturation at $95^{\circ} \mathrm{C}$ for $3 \mathrm{~min}$, followed by 35 cycles of denaturation at $95^{\circ} \mathrm{C}$ for $15 \mathrm{~s}$, annealing at $53.5^{\circ} \mathrm{C}$ for $15 \mathrm{~s}$, an extension at $72^{\circ} \mathrm{C}$ for $15 \mathrm{~s}$, and a final extension at $72^{\circ} \mathrm{C}$ for $1 \mathrm{~min} / \mathrm{kb}$. 
Fig. 1. Multiple lesions of cauliflower-like warts. a Submandibular region. b Teat papilloma.

Table 3. Animals with cutaneous papilloma
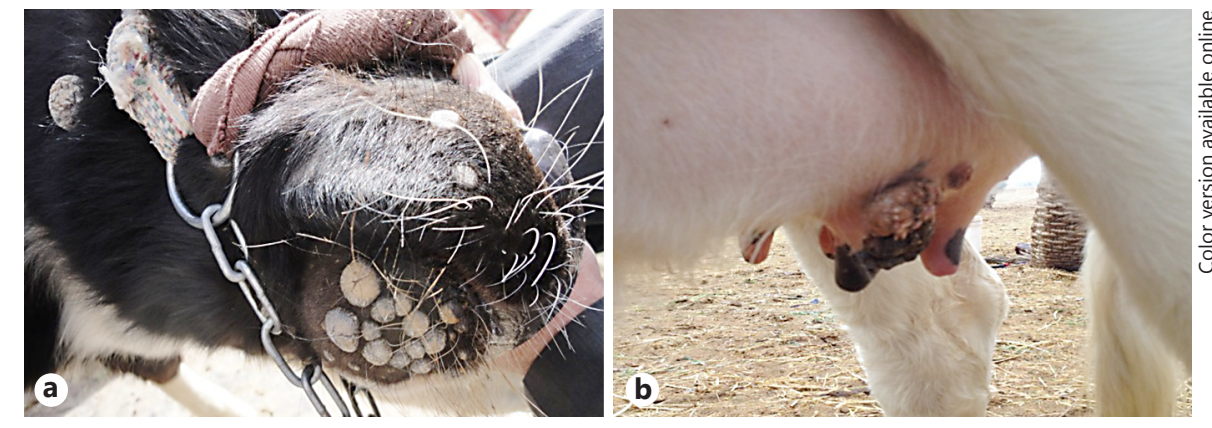

\begin{tabular}{lrlll}
\hline Sex & Animals & Age, months & \multicolumn{2}{l}{ Wilson } \\
\cline { 4 - 5 } & & $\begin{array}{l}\text { proportion/ } \\
\text { prevalence }\end{array}$ & $95 \%$ CI \\
\hline Female & $129(79.14)$ & $16-40(28.57)$ & 0.7914 & $0.7227-0.8467$ \\
Male & $34(20.85)$ & $17-29(23.60)$ & 0.2086 & $0.1533-0.2773$ \\
\hline
\end{tabular}

Values are presented as numbers (\%) or medians (range) unless otherwise stated.
The PCR products of the viral DNA were detected via electrophoresis on a $1.5 \%$ agarose gel containing ethidium bromide, which was placed in a TBE buffer and ran at a constant voltage $(100 \mathrm{~V})$ for approximately $35 \mathrm{~min}$. The DNA was visualized using a VISION gel documentation system (Scie-Plas, Cambridge, UK). As a negative control, DNA was extracted from tissues collected from clinically healthy slaughtered cattle that had previously shown negative results in both histological and PCR analyses. Internal controls for the quality of DNA extracts were included.

\section{Statistical Analysis}

Data were analyzed statistically using SPSS Statistics software (IBM SPSS Statistics for Windows version 22.0; IBM Corp., Armonk, NY, USA). Specific group differences were determined using least significant differences. The confidence level probability of detection was calculated with prevalence rates with 95\% CI in samples as identified by PCR that were calculated as Wilson (score) intervals in OpenEpi Logistic regression analyses (http://www. openepi.com/Menu/OE_Menu.htm).

\section{Results}

The 163 animals included in this study had cauliflower-like cutaneous papillomas (warts). The sample included 129 females $(79.14 \%)$ with an age range of 16-40 months and 34 males (20.85\%) with an age range of 17-29 months; the incidence rate was significantly higher in females than in males $(p<0.05$; Table 3$)$.
Warts were cauliflower-like, dome-shaped papillae with smooth outer surfaces and varied in number from 1 to multiple warts. The most commonly affected sites were the teats and neck (Fig. 1a, b), though the warts were found in other areas of the body, as shown in Table 4.

\section{Gross and Macroscopic Pathology}

Most warts were of variable sizes, rough and irregular in surface, grayish/blackish/flesh colored, irregular in shape (dome or button), and elevated from the skin surface, and they were diagnosed as fibropapilloma/papilloma. Histological sections showed epidermal and dermal interdigitations (papillary projections) as well as fibroblast proliferations (Fig. 2a). They were characterized by the presence of koilocytes, keratohyaline granules, and inclusion bodies (Fig. 2b).

\section{PCR}

The results found that 121 of the extracted papilloma DNA from the cutaneous lesions (80.13\%) of 151 samples showed 1 DNA fragment ( $847 \mathrm{bp}$ ), which corresponds to genotype BPV-1 (Fig. 3a). Twelve of these extracted papilloma DNA samples (7.94\%) showed mixed infections, with BPV-1 and another DNA fragment (413 bp) corresponding to the genotype BPV-13, as seen in Figure $3 \mathrm{~b}$. This result indicated a mixed infection in the examined papilloma lesions and is shown in Table 5. 
Fig. 2. Histopathological sections of warts on cow skin. a Epidermal and dermal interdigitations and papillary projections at $\times 10$ magnification. b Koilocytes with swollen perinuclear halo keratinocytes (black arrow) and some koilocytes with clear cytoplasm and pyknotic nuclei (white arrow) at $\times 40$ magnification (hematoxylin and eo$\sin )$.
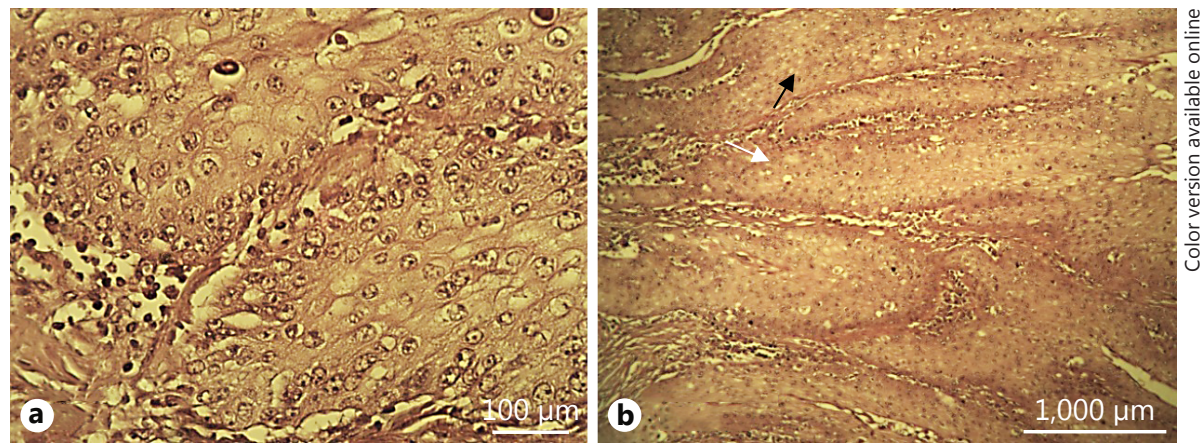

Table 4. Lesion sites

\begin{tabular}{lrll}
\hline Lesion site & Females, $n$ & Males, $n$ & Total, $n(\%)$ \\
\hline Neck & 15 & 7 & $22(13.49)$ \\
Teats & 20 & 0 & $20(12.26)$ \\
Forehead & 8 & 5 & $13(7.97)$ \\
Back & 8 & 3 & $11(6.74)$ \\
Ear region & 11 & 0 & $11(6.74)$ \\
Muzzle & 5 & 4 & $9(5.52)$ \\
Tail & 8 & 0 & $8(4.90)$ \\
Around the eye & 7 & 1 & $8(4.90)$ \\
Submandibular & 5 & 3 & $8(4.90)$ \\
Legs & 8 & 0 & $8(4.90)$ \\
Udder attachment & 6 & 0 & $6(3.68)$ \\
Abdomen & 5 & 1 & $6(3.68)$ \\
Thigh & 4 & 1 & $5(3.06)$ \\
Front region & 1 & 4 & $5(3.06)$ \\
Udder & 5 & 0 & $5(3.06)$ \\
Shoulder & 5 & 0 & $5(3.06)$ \\
Left flank & 3 & 2 & $5(3.06)$ \\
Pin bone & 1 & 2 & $3(1.84)$ \\
Nose & 2 & 1 & $3(1.84)$ \\
Throat & 2 & 0 & $2(1.22)$ \\
\hline
\end{tabular}

Thirteen of the 32 DNA blood samples showed 2 DNA fragments (847 and $603 \mathrm{bp}$ ) corresponding to both genotypes BPV-1 and BPV-2, as shown in Figure 3c. The esophageal lesions showed negative results for BPV genotypes, which means that there is another causative agent that induces such tumors.

\section{Discussion}

In the current study, clinically and histologically diagnosed cases of bovine papillomatosis were considered to recognize and distinguish the BPV genotypes that cause the infection in central Iraq, which is the major region for
Table 5. The total positive and negative samples from different body parts and their BPV genotypes

\begin{tabular}{llrrr}
\hline Samples & $\begin{array}{l}\text { Positive } \\
\text { results }\end{array}$ & BPV-1 & BPV-2 & BPV-13 \\
\hline Cutaneous & Pure & 121 & 0 & 0 \\
papilloma & Mixed & 12 & 0 & 12 \\
& Negative & & 18 & \\
\cline { 2 - 5 } & Total & & 151 & \\
\hline Blood & Pure & 12 & 0 & 0 \\
& Mixed & 13 & 13 & 0 \\
& Negative & & 7 & \\
\cline { 2 - 5 } & Total & & 32 & \\
\hline Esophageal & Pure & 0 & 0 & 0 \\
lesion & Mixed & 0 & 0 & 0 \\
& Negative & & 5 & \\
\cline { 2 - 5 } & Total & & 5 & \\
& & &
\end{tabular}

Values are presented as numbers. BPV, bovine papilloma virus.

large cattle breeding farms. Identification and characterization of the BPV genotypes are important for effective disease control. We used specific primers for each genotype to allow the identification and characterization of many viral types.

The incidence rate of bovine papillomatosis was significantly higher in females than in males $(p<0.05)$. Salib and Farghali [35] reported similar findings and showed that the prevalence was higher in females $(2.99 \%)$ than males $(1.87 \%)$. Female cattle are often stressed by gestation and lactation, which might help to explain this phenomenon. Moreover, the age range of the females included in our sample was longer than that for males, as male cattle are usually slaughtered for meat production in less 


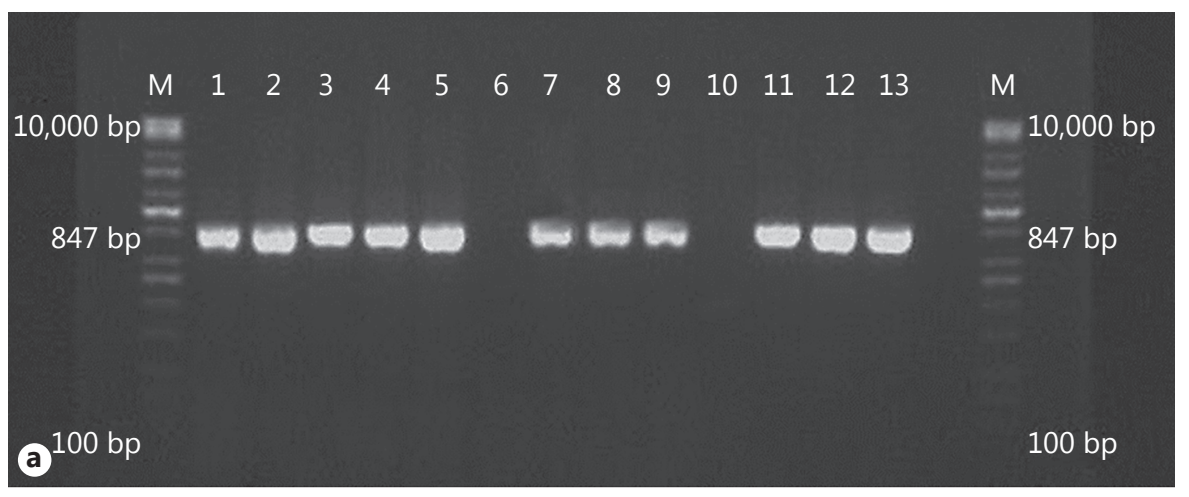

Fig. 3. PCR products in ethidium-bromide-stained $1.5 \%$ agarose in TBE gel electrophoresis. a Skin wart samples: $\mathrm{M}=100$ to 10,000-bp marker; L1, L2, L3, L4, L5, L7, L8, L9, L11, L12, and L13 are monoinfections with BPV-1 (847 bp); L6 and L10 represent the negative control (NTC). $\mathbf{b} \mathrm{M}=$ 100 - to 10,000-bp marker; L1, L2, and L3 showed mixed infections with BPV-1 and BPV-13 (847 and 413 bp, respectively). c Blood samples; L1, L2, L3, and L4 showed mixed infections of BPV-1 and BPV-2 (847 and $603 \mathrm{bp}$, respectively).

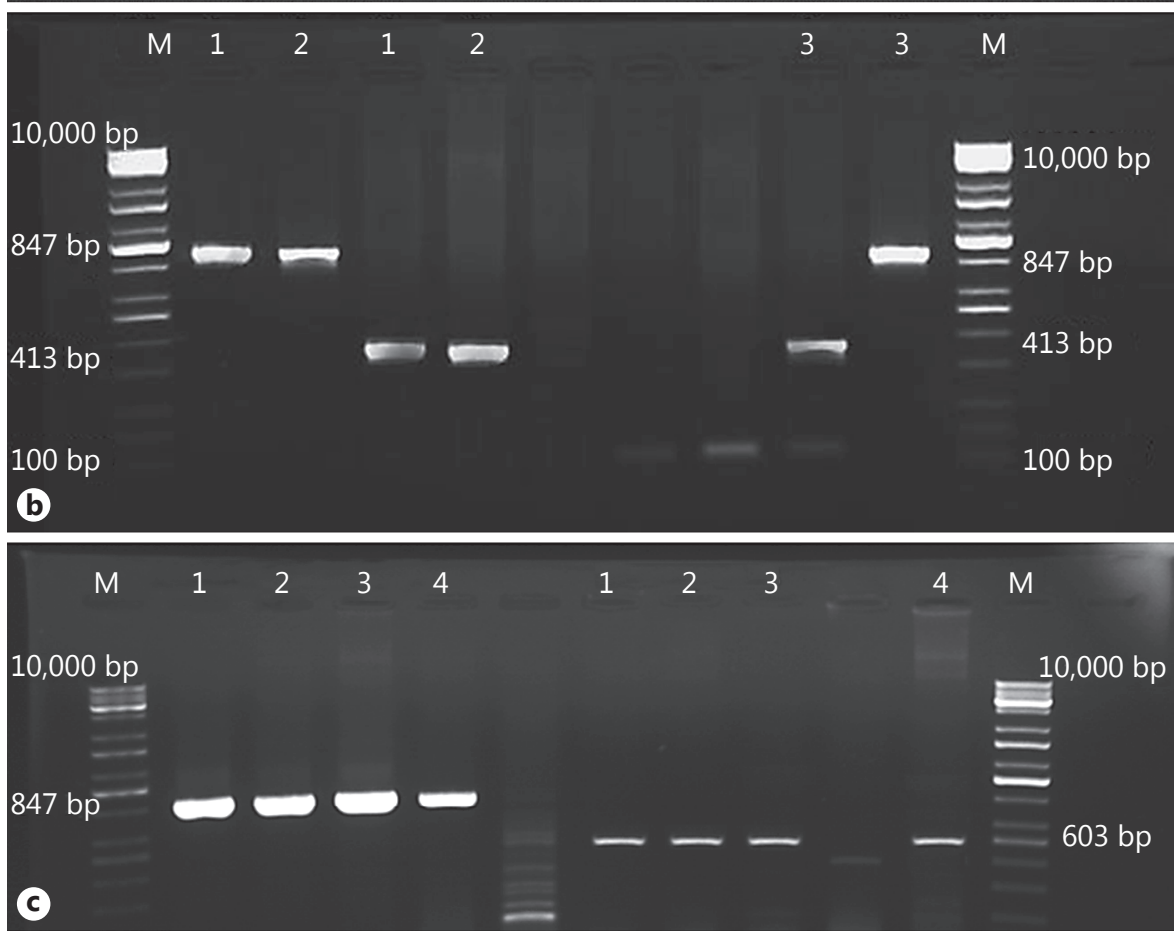

than 2 years. Additionally, the percentage of bovine papillomatosis in cattle is greater than in buffalo, where only a few cases have been reported [36].

In the current work, bovine warts were found in different parts of the body. The most commonly affected sites were the teats and neck, though warts were also found in other areas of the body. De Villiers et al. [37] reported similar results. McMurray et al. [38] indicated that bovine papillomas differ in their tissue specificity depending on the genotype of the virus and the associated disease. A latent infection of BPV in the skin has been demonstrated widely in cattle [39].

Histological findings showed that the wart specimens in this study were mostly cutaneous fibropapillomas, which had the characteristic feature of pap- illomatosis as described by Marins and Ferreira [40]. In our molecular investigation on tissue samples, we found mixed infections of BPV-1 and BPV-13. These results were also recorded by Lunardi et al. [8], who described cutaneous papillomatosis characterized by the presence of multiple benign exophitic proliferations of the epithelia. At least 14 different types of BPV have been identified, and most of these types are associated with cutaneous papilloma and fibropapilloma. The lesions were composed of a hyperplastic epidermis supported by thin, not clearly visible dermal stalks that were similar to those previously reported by others $[41,42]$. The identification of several genotypes of papilloma virus (BPV-1, BPV-2, and BPV-13) indicated mixed infections, which were widespread in animals with cutane- 
ous warts in diverse portions of their body. These results are in agreement with those of Campos et al. [43], who also found that cattle, as well as buffalo, had mixed infections of BPV-1, BPV-2, and BPV-13 [44]. We did not find any significant differences in lesions, either grossly or histologically, between samples in relation to specific genotypes, meaning that there may need to be specific studies in the future focusing on these parameters.

Other findings in the current study on blood samples showed further mixed infections of BPV-1 and BPV-2. These results were also reported by other researchers, such Lindsey et al. [45] and Araldi et al. [46], who found mixed infections of BPV DNA (BPV1 and BPV2) in the milk, blood, urine, and semen of BPV-infected animals. Furthermore, they reported mixed infections from primary and secondary cultures prepared from cutaneous warts; as these are DNA fragments in different passages of a cell culture, both active viruses (BPV-1 and BPV-2) could be in a latent stage of bovine papilloma. Additionally, the results for the detection of these 2 genotypes (BPV-1 and BPV-2) in blood samples are compatible with those of Vidya Singh et al. [47], who detected BPV-2 in the blood of animals affected by bovine papilloma. In addition, Cota et al. [48] detected BPV-1 and BPV-2 in blood via PCR in different cases of bovine enzootic hematuria, which is characterized by the development of bovine urinary bladder tumors.

The investigation of esophageal tumors in Iraqi cattle did not show BPV as a causative agent, in contrast to the result of Campo et al. [2], who showed that BPV is indeed the causal agent of esophageal cancer in cattle. Causes of esophageal tumors include squamous cell carcinoma and adenocarcinoma of the esophagus. About $40 \%$ of all esophageal cancers were squamous cell cancer, which arises from the cells lining the upper part of the esophagus. Adenocarcinoma of the esophagus accounted for approximately $60 \%$ of all esophageal cancers. It arises from the glandular cells that exist at the junction of the esophagus and the stomach [49].

\section{Conclusions}

This is believed to be the first study on BPV mixed infections of the genotypes 1,2 , and 13 associated with fibropapilloma in cattle in Iraq. There is a wide range of BPV types that infect Iraqi cattle, and an understanding of this diversity is necessary in order to develop new therapeutic methods and control policy.

Molecular Epidemiology of BPV and Identification of Three Genotypes

\section{Acknowledgement}

We thank all of the Experimental Therapy Department staff who contributed to this work, as well as Dr. Ayman Hassan and Aesar Ahmed.

\section{Ethics Statement}

All applicable international, national, and/or institutional guidelines for the care and use of animals were followed. This article does not contain any studies with human participants performed by any of the authors.

\section{Disclosure Statement}

The authors declare that they have no conflict of interests.

\section{Funding Sources}

No external funding was used for this study.

\section{Author Contributions}

Ahmed Majeed Al-Shammari, Shoni M. Odisho, and Nahi Y. Yaseen developed this study and wrote the study design. The experiments were performed by Mohammed A. Hamad and Ahmed Majeed Al-Shammari. Data was collected and analyzed by the entire team. The first draft of this paper was written by Mohammed A. Hamad and Ahmed Majeed Al-Shammari. This paper was revised by all of the authors. All of the authors read and approved the final version of this paper.

References

Intervirology 2017;60:156-164 DOI: $10.1159 / 000486594$
1 Stocco dos Santos RC, Lindsey CJ, Ferraz OP, Pinto JR, et al: Bovine papillomavirus transmission and chromosomal aberrations: an experimental model. J Gen Virol 1998;79:2127-2135

2 Campo MS: Papillomavirus and disease in humans and animals. Vet Comp Oncol 2003; $1: 3-14$.

3 Borzacchiello G, Roperto F: Bovine papillomaviruses, papillomas and cancer in cattle. Vet Res 2008;39:45.

4 Munday JS, Thomson N, Dunowska M, Knight CG, Laurie RE, Hills S: Genomic characterisation of the feline sarcoid-associated papillomavirus and proposed classification as Bos taurus papillomavirus type 14. Vet Microbiol 2015;177:289-295.

5 Lunardi M, Alfieri AA, Otonel RA, de Alcantara BK, et al: Genetic characterization of a novel bovine papillomavirus member of the Deltapapillomavirus genus. Vet Microbiol 2013b;162:207-213. 
6 Nasir L, Reid SW: Bovine papillomaviral gene expression in equine sarcoid tumours. Virus Res 1999;61:171-175.

7 Nasir L, Campo MS: Bovine papillomaviruses: their role in the aetiology of cutaneous tumours of bovids and equids. Vet Dermatol 2008; 19:243-254.

8 Lunardi M, de Alcantara BK, Otonel RA, Rodrigues WB, et al: Bovine papillomavirus type 13 DNA in equine sarcoids. J Clin Microbiol 2013a;51:2167-2171.

9 Jarrett WF, Campo MS, O’Neil BW, Laird $\mathrm{HM}$, et al: A novel bovine papillomavirus (BPV-6) causing true epithelial papillomas of the mammary gland skin: a member of a proposed new BPV subgroup. Virology 1984;136: 255-264.

10 Hatama S, Nobumoto K, Kanno T: Genomic and phylogenetic analysis of two novel bovine papillomaviruses, BPV-9 and BPV-10. J Gen Virol 2008;89:158-163.

11 Gardiner DW, Teifke JP, Podell BK, Kamstock DA: Fibropapilloma of the glans penis in a horse. J Vet Diagn Invest 2008;20:816819.

12 Carvalho CD, Freitas AC, Brunner O, Góes LG, Cavalcante AY, Beçak W, Santos RD: Bovine papillomavirus type 2 in reproductive tract and gametes of slaughtered bovine females. Braz J Microbiol 2003;34:82-84.

13 Roperto S, Brun R, Paolini F, Urraro C, et al: Detection of bovine papillomavirus type 2 in the peripheral blood of cattle with urinary bladder tumours: possible biological role. J Gen Virol 2008;89:3027-3033.

14 Diniz N, Melo TC, Santos JF, Mori E, et al: Simultaneous presence of bovine papillomavirus in blood and in short-term lymphocyte cultures from dairy cattle in Pernambuco, Brazil. Genet Mol Res 2009;8:14741480 .

15 Hatama S, Ishihara R, Ueda Y, Kanno T, et al: Detection of a novel bovine papillomavirus type 11 (BPV-11) using Xipapillomavirus consensus polymerase chain reaction primers. Arch Virol 2011;156:1281-1285.

16 Zhu W, Dong J, Shimizu E, Hatama S, et al: Characterization of novel bovine papillomavirus type 12 (BPV-12) causing epithelial papilloma. Arch Virol 2012;157:85-91.

17 Tomita Y, Literak I, Ogawa T, Jin Z, et al: Complete genomes and phylogenetic positions of bovine papillomavirus type 8 and a variant type from a European bison. Virus Genes 2007;35:243-249.

18 Ogawa T, Tomita Y, Okada M, Shirasawa H Complete genome and phylogenetic position of bovine papillomavirus type 7. J Gen Virol 2007;88:1934-1938.

19 Corteggio A, Altamura G, Roperto F, Borzacchiello G: Bovine papillomavirus E5 and E7 oncoproteins in naturally occurring tumors: are two better than one? Infect Agent Cancer 2013;8:1.
20 Betiol JC, Kignel S, Tristão W, Arruda AC, et al: HPV 18 prevalence in oral mucosa diagnosed with verrucous leukoplakia: cytological and molecular analysis. J Clin Pathol 2012;65: 769-770.

21 Elzein ET, Sundberg JP, Housawi FM, Gameel AA, et al: Genital bovine papillomavirus infection in Saudi Arabia. J Vet Diagn Invest 1991;3:36-38

22 Leto M, Santos Júnior GF, Porro AM, Tomimori J: Human papillomavirus infection: etiopathogenesis, molecular biology and clinical manifestations. An Bras Dermatol 2011; 86:306-317.

23 Carvalho CC, Batista MV, Silva MA, Balbino VQ, et al: Detection of bovine papillomavirus types, co-infection and a putative new BPV11 subtype in cattle. Transbound Emerg Dis 2012;59:441-447.

24 Nascimento GA, Souza EV, Campos-Ferreira DS, Arruda MS, et al: Electrochemical DNA biosensor for bovine papillomavirus detection using polymeric film on screen-printed electrode. Biosens Bioelectron 2012;38: 61-66.

25 Araldi RP, Melo TC, Diniz N, Mazzuchellide-Souza J, et al: Bovine papillomavirus clastogenic effect analyzed in comet assay. Biomed Res Int 2013;2013:630683.

26 Ogawa T, Tomita Y, Okada M, Shinozaki K, et al: Broad-spectrum detection of papillomaviruses in bovine teat papillomas and healthy teat skin. J Gen Virol 2004;85:2191-2197.

27 Zheng ZM, Baker CC: Papillomavirus genome structure, expression, and post-transcriptional regulation. Front Biosci 2006;11: 2286-2302.

28 Özsoy SY, Özyildiz Z, Güzel M: Clinical, pathological and immunohistochemical findings of bovine cutaneous papillomatosis. Thorax 2011;7:7-14.

29 Elzein ET, Sundberg JP, Housawi FM, Gameel AA, Ramadan RO, Hassanein MM: Genital bovine papillomavirus infection in Saudi Arabia. J Vet Diagn Invest 1991;3:3638.

30 Hemmatzadeh F, Fatemi A, Amini F: Therapeutic effects of fig tree latex on bovine papillomatosis. J Vet Med B Infect Dis Vet Public Health 2003;50:473-476.

31 Hamad MA, Al-Shammari AM, Odisho SM, Yaseen NY: Molecular and phylogenetic analysis of bovine papillomavirus type 1: first report in Iraqi Cattle. Adv Virol 2016;2016: 2143024.

32 Hamad MA, Al-Banna AS, Yaseen NY: Cell culture established from warts of bovine papilloma. Al-Anbar J Vet Sci 2006;4:77-81.

33 Hamad MA, Al-Banna AS, Yaseen NY: Treatment of bovine papilloma. Proceedings Eleventh Vet Sci Conf, Baghdad, 2012, p 32.

34 Al-Samarai FR, Al-Anbari NN, Al-tmimi YK: Genetics aspects of reproductive performance for Holstein. Iraqi J Vet Sci 2006;30:95-107.
35 Salib FA, Farghali HA: Clinical, epidemiological and therapeutic studies on bovine papillomatosis in Northern Oases, Egypt in 2008 Vet World 2011;4:53-59.

36 Somvanshi R: Papillomatosis in buffaloes: a less-known disease. Transbound Emerg Dis 2011;58:327-332.

37 De Villiers EM, Fauquet C, Broker TR, Bernard HU, Zur Hausen H: Classification of papillomaviruses. Virology 2004;324:17-27.

38 McMurray HR, Nguyen D, Westbrook TF, McAnce DJ: Biology of human papillomaviruses. Int J Exp Pathol 2001;82:15-33.

39 Radostits OM, Gay CC, Hinchcliff KW, Constable PD: Veterinary Medicine: Textbook of the Diseases of Cattle, Horses, Sheep, Pigs and Goats, ed 10. Philadelphia, Saunders Elsevier, 2007

40 Marins RS, Ferreira CEP: Clinicopathologic and epithelial regression study in cutaneous warts of bovines infected by papillomavirus. Int Res J Pharm Pharmacol 2011;1:012-016.

41 Leishangthem GD, Somvanshi R, Lauren DR: Pathological studies on bovine papilloma virus-fern interaction in hamsters. Ind J Exp Biol 2008;46:100-107.

42 Turk N, Zupancic Z, Staresina V, Kovac S, Babic T, et al: Severe bovine papillomatosis: detection of bovine papillomavirus in tumour tissue and efficacy of treatment using autogenous vaccine and parammunity inducer. Vet Arh 2005;75:391-397.

43 Campos RS, Trindade C, Ferraz OP, Giovanni DN, Lima AA, et al: Can established cultured papilloma cells harbor bovine papillomavirus? Gen Mol Res 2008;7:1119-1126.

44 Kumer P, Nagarajan N, Kumar D, Bind RB, Somvanshi R: Detection and quantification of bovine papillomaviruses (BPVs) in cutaneous warts of cattle and buffaloes. Adv Anim Vet Sci 2013;1:53-58

45 Lindsey CJ, Almeida ME, Vicari CF, Carvalho C, Yaguiu A, at al: Bovine papilloma-virus DNA in milk, blood, urine, semen, and spermatozoa of bovine papillomavirus-infected animals. Gen Mol Res 2009;8:310-318.

46 Araldi RP, Carvalho RF, Melo TC, Diniz NSP Sant'Ana TA, et al: Bovine papillomavirus in beef cattle: first description of BPV-12 and putative type BAPV8 in Brazil. Genet Mol Res 2014;13:5644-5653.

47 Vidya Singh R, Somvanshi T, Yasotha SK, Subodh SK, Shanker D: Detection of BPV-2 in cutaneous warts of Indian water buffaloes (Bubalus bubalis). Buffalo Bull 2010;2:133-140.

48 Cota JB, Peleteiro MC, Letti L, Tavares L, Duarte A: Detection and quantification of bovine papillomavirus type 2 in urinary bladders and lymph nodes in cases of bovine enzootic hematuria from the endemic region of Azores. Vet Microbiol J 2015; 178:138-143.

49 Borzacchiello G, Ambrosio V, Roperto S, Poggiali F, Tsirimonakis E, Venuti A, Campo MS, Roperto F: Bovine papillomavirus type 4 in oesophageal papillomas of cattle from the south of Italy. J Comp Pathol 2003;128:203206. 